Article

\title{
Bitter Orange (Citrus aurantium Linné) Improves Obesity by Regulating Adipogenesis and Thermogenesis through AMPK Activation
}

\author{
Jinbong Park ${ }^{1,2,+}$, Hye-Lin Kim ${ }^{1,+}$, Yunu Jung ${ }^{1,2} \mathbb{D}$, Kwang Seok Ahn ${ }^{1,2} \mathbb{D}$, \\ Hyun Jeong Kwak ${ }^{3, *(D)}$ and Jae-Young Um 1,2,* \\ 1 College of Korean Medicine, Kyung Hee University, Seoul 02447, Korea \\ 2 Basic Research Laboratory for Comorbidity Regulation, Comorbidity Research Institute, \\ Kyung Hee University, Seoul 02447, Korea \\ 3 Life Science Major, Division of Bio-Convergence, College of Convergence and Integrate Science, \\ Kyonggi University, Suwon 16227, Korea \\ * Correspondence: hjkwak@kyonggi.ac.kr (H.J.K.); jyum@khu.ac.kr (J.-Y.U.); \\ Tel.: +82-31-249-9294 (H.J.K.); +82-2-961-9262 (J.-Y.U.) \\ + These authors contributed equally to this work.
}

Received: 19 July 2019; Accepted: 18 August 2019; Published: 22 August 2019

check for updates

\begin{abstract}
Obesity is a global health threat. Herein, we evaluated the underlying mechanism of anti-obese features of bitter orange (Citrus aurantium Linné, CA). Eight-week-administration of CA in high fat diet-induced obese C57BL/6 mice resulted in a significant decrease of body weight, adipose tissue weight and serum cholesterol. In further in vitro studies, we observed decreased lipid droplets in CA-treated 3T3-L1 adipocytes. Suppressed peroxisome proliferator-activated receptor gamma $(\mathrm{PPAR} \gamma)$ and CCAAT/enhancer binding protein alpha indicated CA-inhibited adipogenesis. Moreover, CA-treated primary cultured brown adipocytes displayed increased differentiation associated with elevation of thermogenic factors including uncoupling protein 1 and PPAR $\gamma$ coactivator 1 alpha as well. The effects of CA in both adipocytes were abolished in AMP-activated protein kinase alpha $(\mathrm{AMPK} \alpha)$-suppressed environments, suggesting the anti-adipogenic and pro-thermogenic actions of CA were dependent on AMPK $\alpha$ pathway. In conclusion, our results suggest CA as a potential anti-obese agent which regulates adipogenesis and thermogenesis via AMPK $\alpha$.
\end{abstract}

Keywords: bitter orange; obesity; adipogenesis; thermogenesis; AMP-activated protein kinase

\section{Introduction}

Obesity (body mass index, BMI > $30 \mathrm{~kg} / \mathrm{m}^{2}$ ) has risen into a serious health threat worldwide, especially in developed countries [1]. According to an analytic study of 19.2 million participants from 1975 to 2014, age-standardized BMI increased from 21.7 to $24.2 \mathrm{~kg} / \mathrm{m}^{2}$ in men and 22.1 to $24.4 \mathrm{~kg} / \mathrm{m}^{2}$ in women globally. Speculations based on this trend expects obesity prevalence of 2025 as $18 \%$ in men and $21 \%$ in women worldwide [2]. This global trend in concerning, as obesity is associated with high risks of comorbidities such as type 2 diabetes mellitus [3], cardiovascular diseases [4] and even certain cancers [5].

Obesity is a complex status in which multiple factors participate. Above all, when energy consumption exceeds expenditure, the surplus energy is stored as lipid, specifically triglyceride, in white adipose tissues (WATs) [6]. While WAT works as a storage unit to save excessive energy, brown adipose tissue (BAT), on the other hand, functions in an opposite way. BAT is an organ which can dissipate energy as heat in response to cold exposure or other stimuli such as pharmacological 
agents [7]. This process, the non-shivering thermogenesis, is mediated by the mitochondrial uncoupling protein 1 (UCP1), which shunts the proton circuit and leads to heat production instead of ATP [8].

Adipogenesis is the differentiation process of which preadipocytes develop into a mature status associated with accumulation of lipid droplets. Excessive lipid accumulation in WAT is both the cause and main symptom of obesity [9]. Multiple processes regulate adipogenesis, including adipocyte proliferation and differentiation or fatty acid oxidation and synthesis, and are controlled by numerous factors [10]. Studies suggest peroxisome proliferator-activated receptor gamma (PPAR $\gamma$ ) and CCAAT/enhancer binding protein alpha $(\mathrm{C} / \mathrm{EBP} \alpha)$ as the key regulators of this process $[11,12]$. Inhibiting these two factors appears to be an attractive strategy for obesity treatment, because excessive growth of WAT in obese individuals has been suggested to be caused from not only proliferation of adipocytes but also a result of adipocyte hypertrophy by increased lipid accumulation in newly matured adipocytes as a result of adipogenesis [13,14].

Besides reducing accumulated lipid within WAT, regulation of BAT differentiation and activation is another attractive target for obesity care. BAT, first identified in the 1960's, is a tissue organ which can dissipate energy in the form of heat; non-shivering thermogenesis. Thermogenesis in BAT is controlled by the activation of sympathetic nervous system (SNS), which releases noradrenaline (NA) to activate the $\beta 3$-adrenergic receptor ( $\beta 3$-AR) in brown adipocytes [15-17]. In response to the activation of $\beta 3-A R$, mitochondrial UCP1 provides a proton leak into the existing potential difference in the mitochondrial membrane, shunts the ATP-synthesizing respiratory chain, and results in facilitation of heat production. In the perspective of enery expenditure (EE), the activation of BAT has gained interest as a new promising therapeutic target for obesity management.

Bitter orange (Citrus aurantium Linné, CA), of which Latin name is Aurantii Fructus Immaturus, is also called as Seville Orange, sour orange or marmalade orange, and has found as a beverage and a dietary supplement on the market. Recent studies report the hepatoprotective [18], anti-cancer [19,20], anxiolytic [21,22], anti-oxidant [23,24] effects of CA. Furthermore, a number of studies have elucidated its beneficial effect on metabolic diseases as well [25-28]. However, up to date, regardless of the studies reporting various functions of $\mathrm{CA}$, there has been no study investigating the influence of $\mathrm{CA}$ on brown adipocyte differentiation and activation. Here, our study were aimed to examine the anti-adipogenic and thermogenic mechanisms of CA in 3T3-L1 adipocytes and primary brown adipocytes, and in addition, elucidate the role of AMP-activated protein kinase (AMPK) in the action of CA.

\section{Materials and Methods}

\subsection{Preparation of $C A$}

CA, also called as Jigak in Korea, was purchased from Omniherb, Co. (Daegu, Republic of Korea). A voucher specimen of CA has been deposited in the College of Korean Medicine, Kyung Hee University (Seoul, Republic of Korea). CA was extracted with 80\% ethanol for $2 \mathrm{~h} 20 \mathrm{~min}$ in a heating mantle. The solvents were filtered, freeze-dried (Rotary evaporator Model NE-1 and Freeze dryer FD-1, Tokyo, Japan), and then stored at $-80^{\circ} \mathrm{C}$ until usage. The yield (w/v) was $25 \%$.

\subsection{Chemical Reagents and Antibodies}

3-isobutyl-1-methylxanthine (IBMX), compound C (CC), dexamethasone (Dex), indomethacin, insulin, and Oil Red O powder were purchased from Sigma-Aldrich Co. (St Louis, MO, USA). Bovine serum (BS), Dulbecco's modified Eagle's medium (DMEM), penicillin/streptomycin/glutamine (P/S/G) and were obtained from Gibco (Grand Island, NY, USA). Fetal bovine serum (FBS) was purchased from HyClone Laboratories Inc. (Logan, UT, USA).

Anti-C/EBP $\alpha$, anti-glyceraldehyde-3-phosphate dehydrogenase (GAPDH), anti-PPAR $\gamma$ coactivator 1 alpha (PGC1 $\alpha$ ) and anti-UCP1 antibodies were purchased from Santa Cruz Biotechnology, Inc. (Santa Cruz, CA, USA), and antibodies for AMPK $\alpha$, pAMPK $\alpha$, acetyl-CoA carboxylase (ACC), pACC, liver 
kinase B1 (LKB1), pLKB1 and PPAR $\gamma$ were purchased from Cell Signaling Technology, Inc. (Beverly, MA, USA).

\subsection{Chromatographic Separation}

The high-performance liquid chromatography (HPLC) analysis was performed with a vacuum degasser, a quaternary pump and an automatic sample injection system. The column Nucleosil C18 $(150 \times 4.6 \mathrm{~mm}, 5 \mu \mathrm{m}$, Teknokroma, Barcelona, Spain) separated the sample, $80 \%$ ethanol extract of CA, as the mobile phase at a flow rate of $1.0 \mathrm{ml} / \mathrm{min}$ at $25^{\circ} \mathrm{C}$. Initial elution was performed by acetonitrile-aqueous ammonium acetate $35: 65(\mathrm{v} / \mathrm{v})$. After $30 \mathrm{~min}$, the linear gradient reached $60 \%$ acetonitrile.

\subsection{Ethics Statement}

All animal experiment procedures were approved by the Animal Care and Use Committee of the Institutional Review Board of the Kyung Hee University (confirmation number: KHUASP (SE)-13-012).

\subsection{Animals and Diets}

Four-week-old male C57BL/6J mice (Daehan Biolink Co.,Eumsung, Korea) were maintained 1 week prior to the experiments for acclimatization. The mice were fed with a $60 \% \mathrm{kcal} \mathrm{high} \mathrm{fat} \mathrm{diet}$ (HFD) (Rodent diet D12492, Research diet, New Brunswick, NJ, USA) for 4 weeks to induce obesity in accordance with our previous reports [29-31]. Then, mice were divided into two groups $(n=5)$, fed for eight additional weeks with either a) HFD and b) HFD plus CA (100 mg/kg/day). The administration dose of CA was decided based on a previous study [32]. A group fed normal chow diet (ND) for twelve weeks were used as normal control. Body weight was measured two times per week. The composition of each diet is displayed in Supplementary Table S1.

\subsection{Serum Analysis}

The serum was separated by centrifugation $(4000 \times g, 30 \mathrm{~min})$ immediately after blood harvest via cardiac puncture. High-density lipoprotein (HDL) cholesterol, low-density lipoprotein (LDL) cholesterol and total cholesterol (TC) were assayed using a colorimetric enzyme-linked immunosorbent assay (ELISA) method.

\subsection{Cell Culture and Differentiation}

Murine 3T3-L1 preadipocytes were purchased from the American Type Culture Collection (Rockville, MD, USA), cultured in $10 \% \mathrm{BS} / \mathrm{DMEM}$ at $37^{\circ} \mathrm{C}, 5 \% \mathrm{CO}_{2}$ and differentiated into mature white adipocytes in 10\% FBS/DMEM plus $0.5 \mathrm{mM} \mathrm{IBMX}, 1 \mu \mathrm{M}$ Dex and $1 \mu \mathrm{g} / \mathrm{mL}$ insulin at $37^{\circ} \mathrm{C}, 5 \%$ $\mathrm{CO}_{2}$ as previously reported [29].

Brown adipocytes were prepared as previously described [31]. Briefly, preadipocytes were isolated from interscapular BAT of new born (post-natal day 1-2) FVB/NJ mice (Daehan Biolink Co.,Eumsung, Korea), cultured in $10 \% \mathrm{BS} / \mathrm{DMEM}$ at $37^{\circ} \mathrm{C}, 5 \% \mathrm{CO}_{2}$ and differentiated into mature brown adipocytes in 10\% FBS/DMEM plus $0.5 \mathrm{mM}$ IBMX, $0.5 \mu \mathrm{M}$ Dex, $20 \mathrm{nM}$ insulin, $125 \mu \mathrm{M}$ indomethacin and $1 \mathrm{nM}$ T3 at $37^{\circ} \mathrm{C}, 5 \% \mathrm{CO}_{2}$.

\subsection{Cytotoxicity Measurement}

Cells were seeded $\left(2 \times 10^{4}\right.$ cell/well $)$ on 96 well plates, stabilized for $24 \mathrm{~h}$, and incubated with various concentrations of CA $(10-1000 \mu \mathrm{g} / \mathrm{mL})$ for additional $48 \mathrm{~h}$. Cell viability was monitored using the cell proliferation 3-(4,5-dimethylthiazol-2-yl)-5-(3-carboxymethoxyphenyl)2-(4-sulfophenyl)-2H-tetrazolium (MTS) kit (Promega Co., Madison, WI, USA) according to the manufacturer's instructions. The absorbance was measured at $490 \mathrm{~nm}$ with a VERSAmax microplate reader (Molecular Devices, Sunnyvale, CA, USA). 


\subsection{Oil Red O Staining}

Intracellular lipid accumulation was measured by an Oil Red O staining assay as described previously [29]. The absorbance was measured at $500 \mathrm{~nm}$ in a VERSAmax microplate reader (Molecular Devices, Sunnyvale, CA, USA).

\subsection{RNA Extraction and Real-Time Reverse Transcription Polymerase Chain Reaction (RT-PCR)}

RNA was extracted using a GeneAllR RiboEx total RNA extraction kit (GeneAll Biotechnology, Seoul, Republic of Korea), cDNA reverse-transcription was performed using a Power cDNA synthesis kit (iNtRON Biotechnology, Seongnam, Republic of Korea), and Real-Time RT-PCR was performed in a Step One Real-Time PCR System (Applied Biosystems, Waltham, MA, USA). as previously reported [31]. The primers used in this study are shown in Supplementary Table S2.

\subsection{Protein Extraction and Western Blot Analysis}

Cells were harvested and then lysed in ice-cold radioimmunoprecipitation assay (RIPA) buffer. The protein concentration was determined using a protein assay reagent (Bio-Rad Laboratories Inc., Hercules, CA, USA). Western blot analysis was performed as previously described [31]. Briefly, equal amounts $(20 \mu \mathrm{g})$ of total protein were resolved by sodium dodecyl sulfate-polyacrylamide gel electrophoresis (SDS-PAGE) (10-12\% based on the size of detecting protein) and transferred to a polyvinylidene difluoride (PVDF) membrane, which were incubated with primary antibodies (overnight, $4{ }^{\circ} \mathrm{C}$ ), and then incubated with the proper horseradish peroxidase-conjugated secondary antibody diluted at 1:10000 dilution (1 h, room temperature (RT)) (Jackson Immuno Research, West Grove, PA, USA).

\subsection{Mitochondrial Microscopic Analysis and Immunofluorescence Staining}

The mitochondrial analysis was performed using a Mito-Tracker Red probes CM-XRos (Invitrogen, Carlsbad, CA, USA) as previously described [30]. Fluorescence signal images were obtained using an IX71 confocal microscope (Zeiss, Oberkochen, Germany).

The immunofluorescence staining was performed as previously described [33]. Briefly, after treatment with or without CA, brown adipocytes were fixed with $4 \%$ formaldehyde and permeabilized with PBS containing $0.25 \%$ Triton X-100. After blocking non-specific binding with 5\% BSA/PBS, the cells were incubated with UCP1 and PGC1 $\alpha$ antibodies in 5\% BSA/PBS (overnight, $4{ }^{\circ} \mathrm{C}$ ), and incubated with fluorescent secondary antibody Alexa Fluor 488 and Alexa Fluor 546 (1 h, RT). Nuclei staining was performed by incubation with 4',6-diamidino-2-phenylindole (DAPI). The immunofluorescence-stained images were acquired using a fluorescence microscope (Logos Biosystems, Anyang, Republic of Korea).

\subsection{Statistical Analysis}

All data were expressed as mean \pm S.E.M., and processed statistically using SPSS 20 for Windows (SPSS Inc., Chicago, IL, USA). Values with $p<0.05$ calculated by a Kruskal-Wallis H test followed by a post hoc test of Bonferroni's method was considered statistically significant.

\section{Results}

\subsection{Chromatographic Characterization of $C A$}

The immature dried fruits of Citrus aurantium Linné were extracted by 80\% ethanol. The result from HPLC chromatogram showed that CA contains two abundant compounds, naringin and neohesperidin (Figure 1). The naringin and neohesperidin was $20.132 \%(0.916 \mathrm{mg} / \mathrm{mL})$ and $14.440 \%(0.657 \mathrm{mg} / \mathrm{mL})$ of the $80 \%$ ethanol extract of CA $4.55 \mathrm{mg} / \mathrm{mL}$, respectively. 

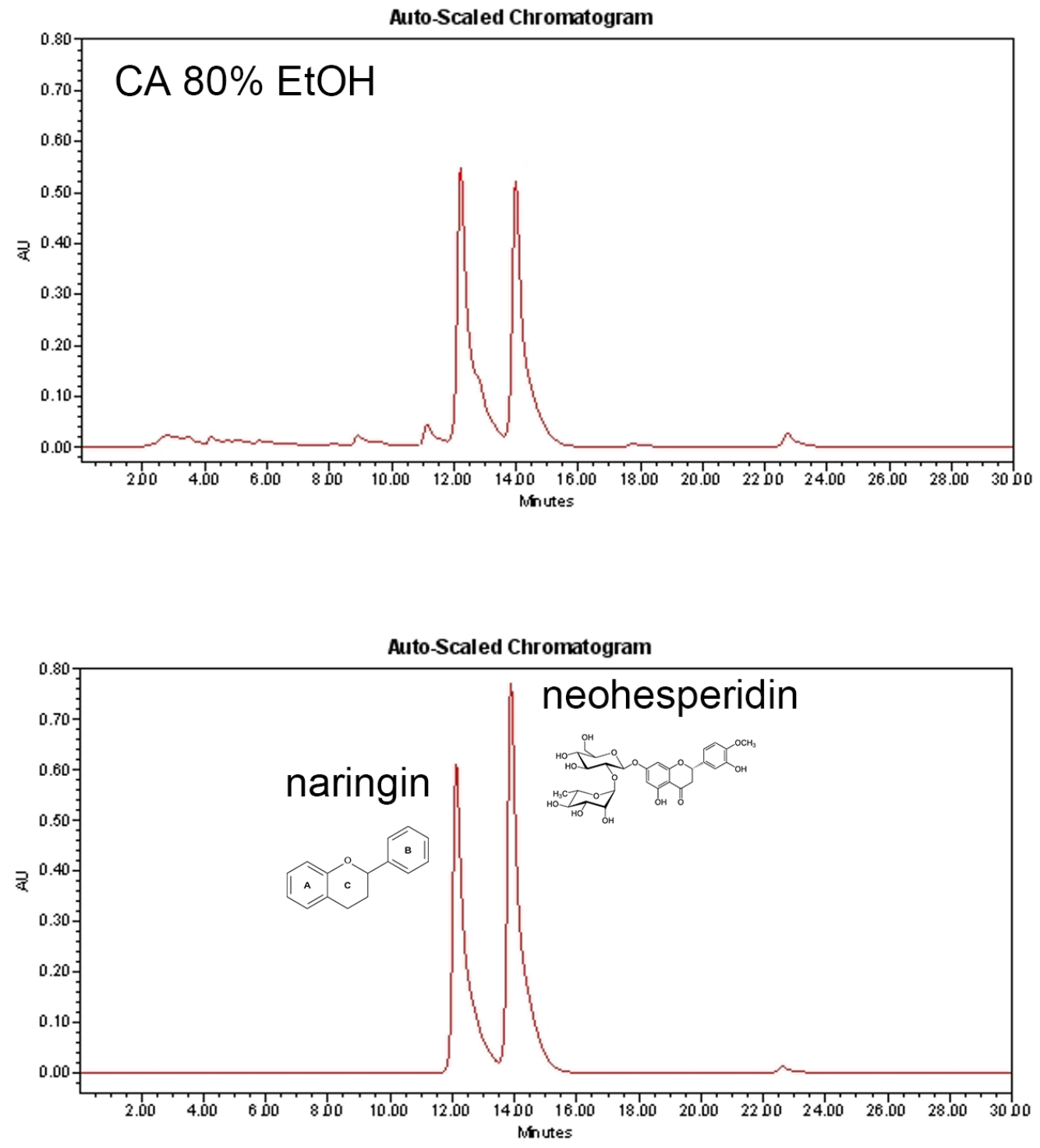

Figure 1. HPLC chromatogram of CA. Each peak displays CA (above) and naringin and neohesperidin (below). CA was extracted with $80 \%$ ethanol. CA, bitter orange (Citrus aurantium Linné).

\subsection{CA Suppressed Body Weight Gain in HFD-induced Obese C57BL/6 Mice}

To investigate whether CA can regulate weight of HFD-fed mice, after inducing obesity with HFD for 4 weeks, CA of $100 \mathrm{mg} / \mathrm{kg} /$ day with HFD was orally administered to C57BL/6 mice for additional 8 weeks. As shown in Figure 2A, HFD group and HFD plus CA group showed significant differences in the gain of body weight at eleventh week $(24.89 \pm 0.21 \mathrm{~g}$ vs. $15.08 \pm 0.97 \mathrm{~g})$. At end of the experiment, the body weights of the two groups were showed significant difference (50.31 $\pm 0.84 \mathrm{~g}$ vs. $40.91 \pm 0.91 \mathrm{~g}$, respectively), adipose tissue weights decreased by $35.64 \%$ in CA-treated obese mice (HFD, $0.56 \pm 0.14 \mathrm{~g}$ vs. CA, $0.36 \pm 0.08 \mathrm{~g}$, $\mathrm{p}=0.0143$ ) (Figure 2B), and the serum total cholesterol level was significantly attenuated by CA in HFD-fed mice (Figure 2C) $(p<0.05)$. 

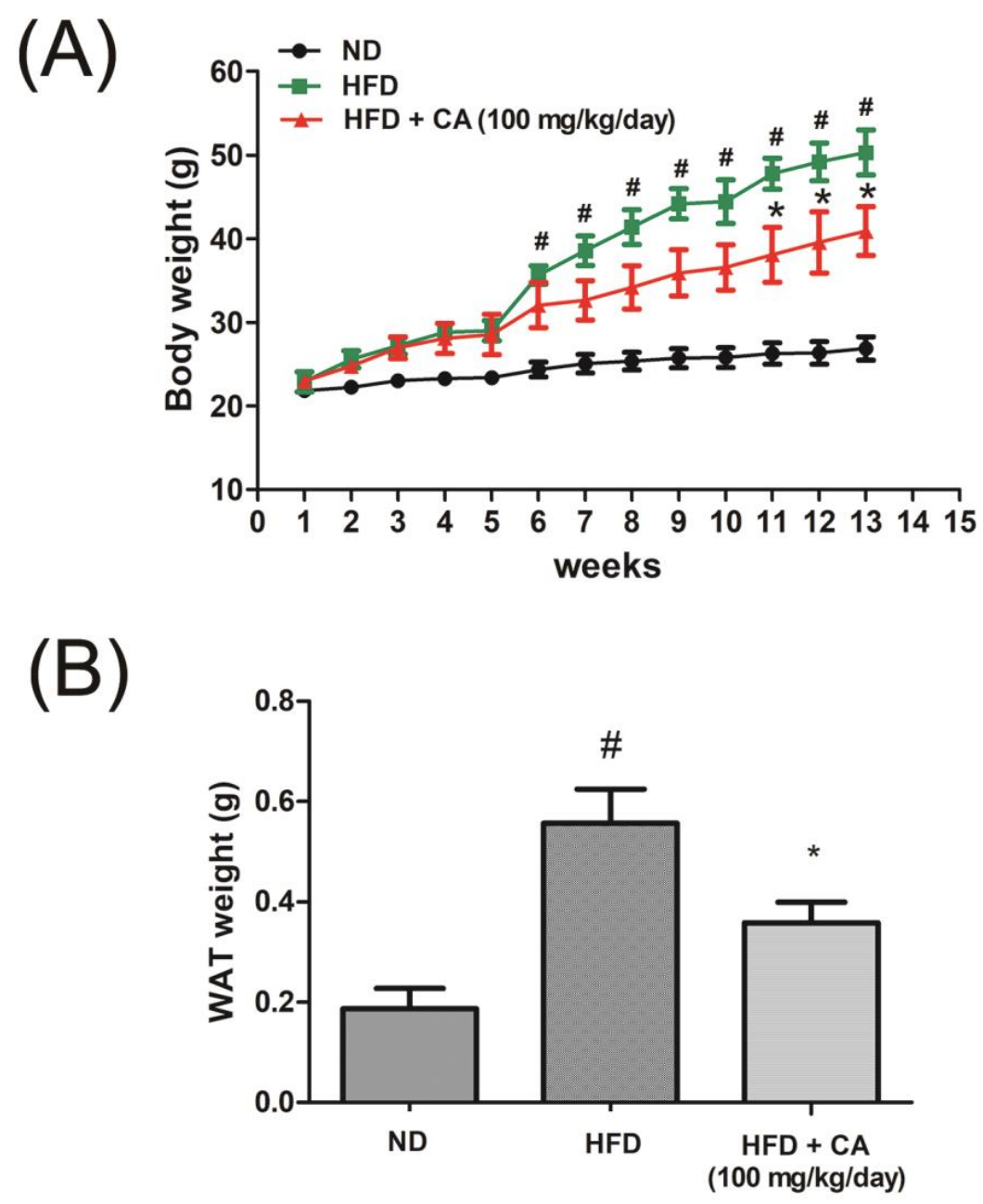

(C)

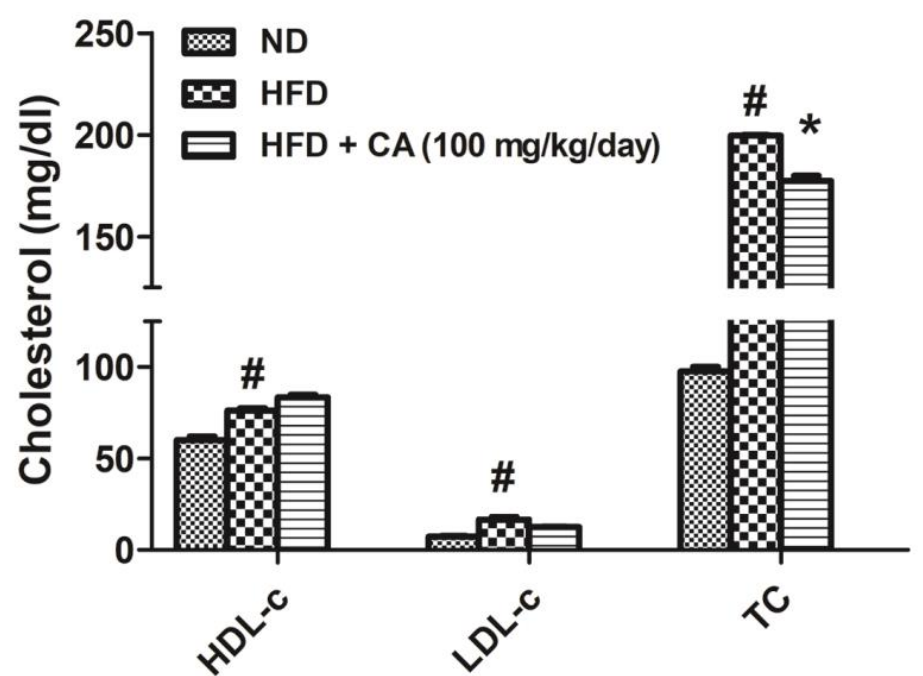

Figure 2. Effect of CA on weight gain in HFD-induced obese mice and on adipogenic differentiation. (A) Body weight and (B) adipose tissue weight changes of C57BL/6J mice. (C) Serum lipid profile of C57BL/6J mice were measured. ${ }^{\#} \mathrm{p}<0.05$ vs. the ND group, ${ }^{*} \mathrm{p}<0.05$ vs. the HFD group. ND, normal diet-fed control group; HFD, high fat diet-fed obese group; CA, high fat diet supplemented with $100 \mathrm{mg} / \mathrm{kg} /$ day bitter orange (Citrus aurantium Linné) -fed obese group. 


\subsection{CA Decreased Lipid Accumulation by Inhibiting Adipogenesis of 3T3-L1 White Adipocytes}

First, to determine the concentration dependent effect of CA $(10-1000 \mu \mathrm{g} / \mathrm{mL})$ on cell viability, 3T3-L1 preadipocytes were applied to MTS reagent. Treatment with 10-1000 $\mathrm{gg} / \mathrm{mL}$ CA for $48 \mathrm{~h}$ did not display any cytotoxic effect in 3T3-L1 cells ( $p>0.05$, Figure 3A), thus we chose concentrations of 100,100 , and $1000 \mu \mathrm{g} / \mathrm{mL}$ for further investigations. Next, to determine whether CA can block white adipogenesis, 3T3-L1 preadipocytes were differentiated with MDI, and the effects of CA were analyzed. As shown in Figure 3B, CA $(1000 \mu \mathrm{g} / \mathrm{mL})$ suppressed lipid accumulation, and this was confirmed by the reduced absorbance of Oil Red $\mathrm{O}(p<0.05)$. At the same time, the mRNA expression involved in white adipogenesis (Pparg, Cebpa, Fabp4, Adipoq and Retn), which were markedly increased during MDI-induced adipogenesis, were attenuated by CA $(1000 \mu \mathrm{g} / \mathrm{mL}$ of CA concentration; $\mathrm{p}=0.032$ for Pparg, $\mathrm{p}=0.041$ for Cebpa, $\mathrm{p}=0.004$ for Fabp4, $\mathrm{p}=0.002$ for Adipoq, and $\mathrm{p}=0.001$ for Retn, respectively) (Figure 3C). In addition, CA treatment reduced levels of $\operatorname{PPAR} \gamma$ and $\mathrm{C} / \mathrm{EBP} \alpha$, which are both well-known key regulators of adipocyte differentiation (Figure 3D).

(A)

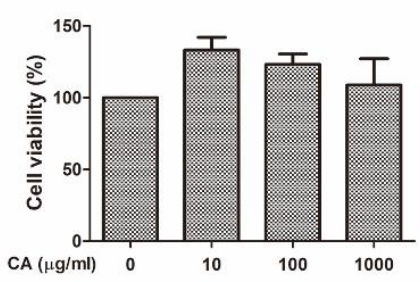

(C)

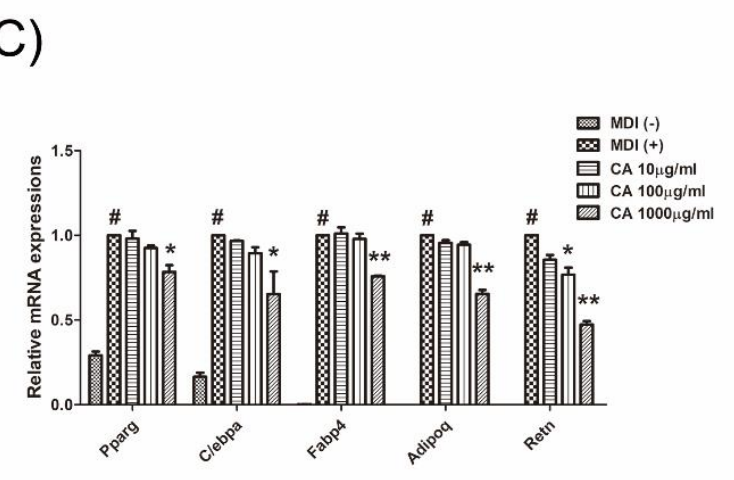

(B)
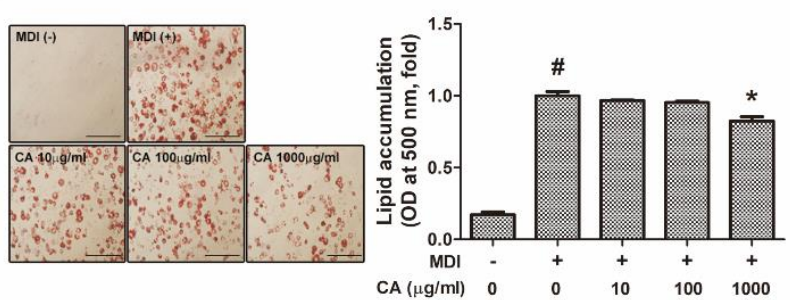

(D)

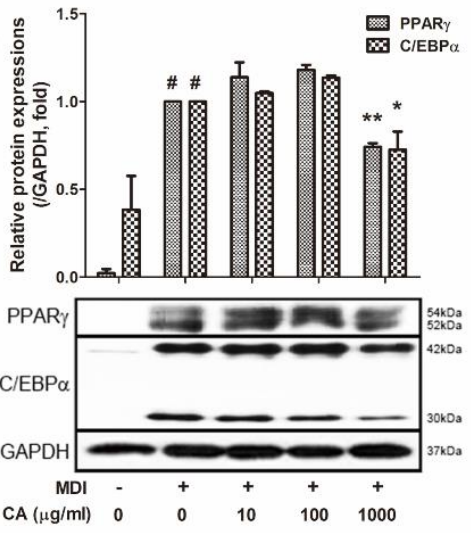

Figure 3. Effect of CA on adipogenesis in 3T3-L1 adipocytes. (A) Cytotoxicity of CA in 3T3-L1 preadipocytes were determined by an MTS assay. (B) Lipid accumulation was measured by Oil Red O staining (magnification 200×, scale bar $100 \mu \mathrm{m}$ ). (C) The mRNA level of Pparg, Cebpa, Fabp4, Adipoq and Retn were analyzed by Real-Time RT-PCR. (D) PPAR $\gamma$ and C/EBP $\alpha$ protein levels were analyzed by a western blot analysis. Quantification of the protein bands was measured using Image J. Results were expressed relative to GAPDH. All data are presented as the mean \pm SEM. ${ }^{\#} p<0.05$ versus the MDI-uninduced preadipocytes, ${ }^{*} p<0.05$ versus the MDI-induced adipocytes, ${ }^{* *} p<0.01$ vs. the MDI-induced adipocytes. MDI, differentiation medium; CA, bitter orange (Citrus aurantium Linné).

\subsection{CA Increased Differentiation of Primary Cultured Brown Adipocytes}

Brown fat specializes in energy expenditure to reduce weight gain through thermogenesis, thus, we evaluated the effect of CA on thermogenesis to explore their involvement with respect to weight loss in HFD-induced obese mice. First, we assessed the cytotoxicity of CA $(10-1000 \mu \mathrm{g} / \mathrm{mL})$ in primary cultured brown adipocytes obtained from interscapular BAT. As in Figure 4A, no specific decrease in brown adipocyte viability was observed in treatment with 10-1000 $\mu \mathrm{g} / \mathrm{mL}$ CA for $48 \mathrm{~h}$. We next investigated whether CA treatment affected the development of primary cultured brown adipocytes 
by treating them with CA (10 or $1000 \mu \mathrm{g} / \mathrm{mL})$ during brown adipocyte differentiation. According to our data, the lipid accumulation at a concentration of $1000 \mu \mathrm{g} / \mathrm{mL}$ of CA were obviously increased $(p<0.05)$ than that of the non-treated control during brown adipocyte differentiation (Figure 4B).

(A)

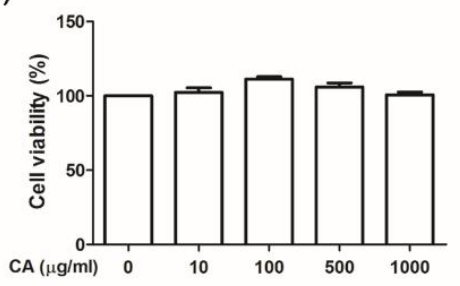

(C)

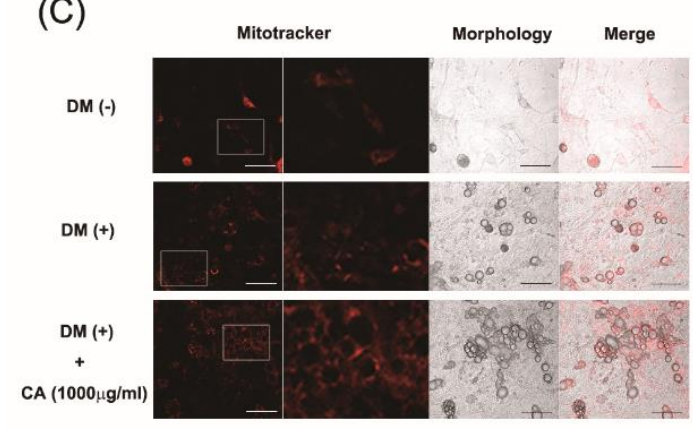

(B)
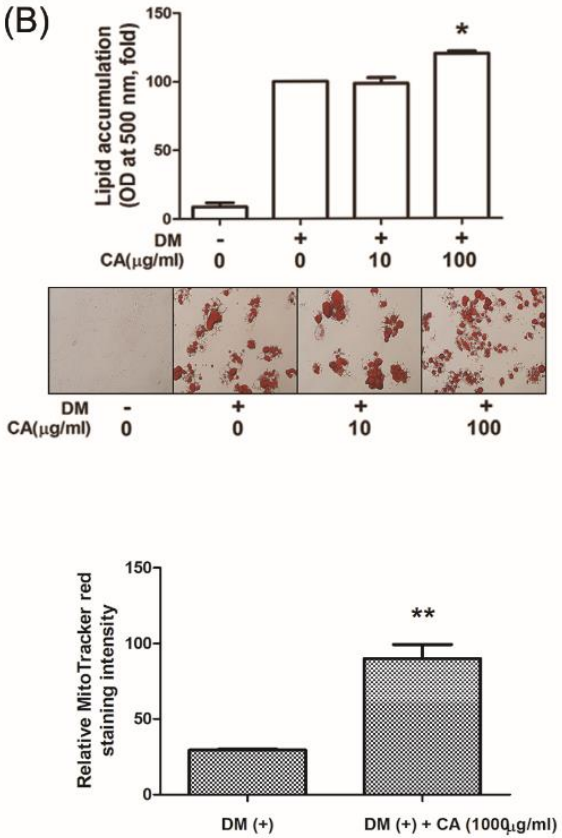

Figure 4. Effect of CA on development of primary cultured brown adipocytes. (A) Cytotoxicity of CA in primary cultured brown preadipocytes were determined by an MTS assay. (B) Lipid accumulation was measured by Oil Red O staining (magnification 200×, scale bar $100 \mu \mathrm{m}$ ). (C) Mitochondrial abundance in primary cultured brown adipocytes was analyzed by MitoTracker Red staining. Quantification of the Mitotracker signaling was measured using Image J from five separate slides. ${ }^{*} p<0.05$ vs. the DM-induced adipocytes, ${ }^{* *} p<0.01$ vs. the DM-induced adipocytes. DM, differentiation medium; CA, bitter orange (Citrus aurantium Linné).

To explore whether the brown adipocyte function agreed to the effect of CA on differentiation, we further focused on the mitochondrial number or mass. We stained brown adipocytes with Mito-Tracker Red, which is a red fluorescent dye that specifically stains mitochondria [34], to observe significantly strong signals in the cytoplasm of CA-treated cells $(\mathrm{p}=0.001)$, which indicates increased mitochondrial copy number (Figure 4C).

\subsection{CA Induced Thermogenic Factors in Primary Cultured Brown Adipocytes}

Multiple factors participate in the differentiation and thermogenic activation of BAT [17]. Our next goal was to elucidate the effect of CA on the related factors in such process. As expected, CA enhanced the mRNA levels of both thermogenic and mitochondrial specific genes, including Pgc1a, Ucp1, Prdm16, Sirt3, Cidea, and CytC (1000 $\mu \mathrm{g} / \mathrm{mL}$ of CA concentration; $p=0.043$ for Pgc1a, $p=0.050$ for Ucp1, $p=0.01$ for Prdm16, $p=0.050$ for Sirt3, $p=0.021$ for Cidea, and $p=0.012$ for CytC) (Figure 5A). We also analyzed protein levels of UCP1 and PGC1 $\alpha$, which were significantly increased by CA at $1000 \mu \mathrm{g} / \mathrm{mL}$ compared to non-treated control during differentiation (Figure $5 \mathrm{~B}$ ), demonstrating the thermogenic effects of $\mathrm{CA}$. After observing an upregulation of UCP1 and PGC1 $\alpha$, we further examined the expression levels of those by using immunofluorescence assay. We observed that the fluorescent protein levels of UCP1 and PGC1 $\alpha$ were markedly induced by CA treatment $(1000 \mu \mathrm{g} / \mathrm{mL})$ during brown adipocytes differentiation $(p=0.001$ for PGC1 $\alpha$ and $p=0.043$ for UCP1) (Figure 5C). 
(A)
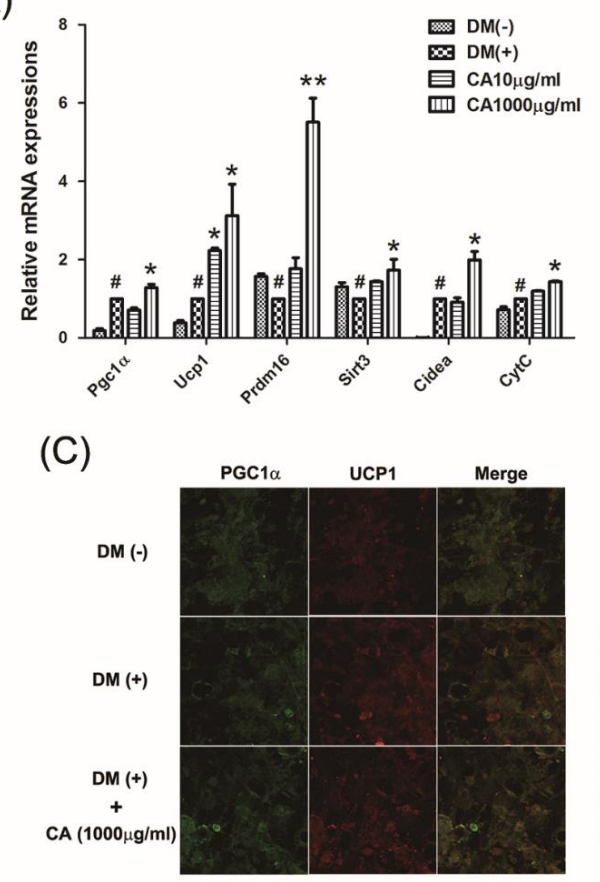

(B)

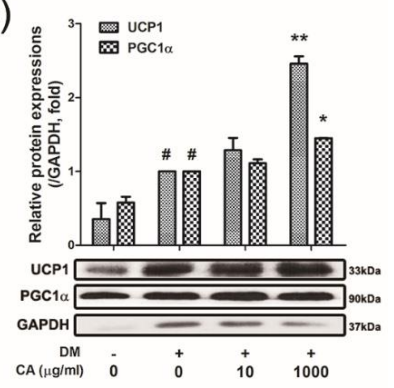

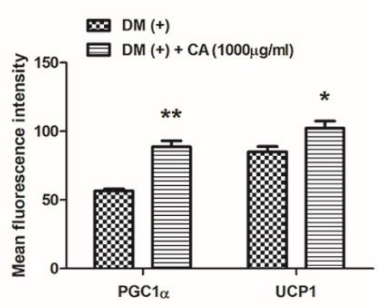

Figure 5. Effect of $\mathrm{CA}$ on thermogenic factors in primary cultured brown adipocytes. (A) The mRNA level of Pgc1a, Ucp1, Prdm16, Sirt3, Cidea and CytC were analyzed by Real-Time RT-PCR. (B) UCP1 and PGC1 $\alpha$ protein levels were analyzed by a western blot analysis. Quantification of the protein bands was measured using Image J. Results were expressed relative to GAPDH. (C) Immunofluorescence staining of UCP1 (red) and PGC1 $\alpha$ (green) were performed (magnification 200×, scale bar $100 \mu \mathrm{m}$ ). Quantification of the immunofluorescence signaling was measured using Image J from five separate slides. All values are means \pm SEM of data from three separate experiments. ${ }^{{ }} p<0.05$ versus DM-uninduced preadipocytes; and ${ }^{*} p<0.05$ and ${ }^{* *} p<0.01$ versus DM-induced adipocytes. DM, differentiation medium; CA, bitter orange (Citrus aurantium Linné).

The recruitment of functional brown adipocytes, also called beige or brite adipocytes, is another rising target for obesity treatment [35]. However, in contrast to results from brown adipocytes, CA failed to induce the thermogenic potential in mature white adipocytes. There was no significant up-regulation in both UCP1 and PGC1 $\alpha$ by CA treatment in 3T3-L1 adipocytes (Supplementary Figure S1).

\subsection{CA Regulated Adipogenesis and Thermogenesis via AMPK Activation}

AMPK, the energy sensor and also the master regulator of metabolic homeostasis, acts to increase glucose uptake, fatty acid oxidation, and mitochondrial biogenesis [36]. In addition, AMPK is involved in both thermogenic activation of BAT and browning of WAT as well as conversion of preadipocytes to mature fat cells [37]. Based on these reports, to elucidate whether the effect of CA on promoting adipogenesis and thermogenesis was dependent on the activation of AMPK, 3T3-L1 adipocytes and primary adipocytes were treated with CA at indicated concentration during differentiation. As a result, CA $(1000 \mu \mathrm{g} / \mathrm{mL})$ in both 3T3-L1 cells and primary brown adipocytes enhanced the levels of pLKB1, the upstream signal of AMPK, pAMPK $\alpha$, and pACC, which is phosphorylated by AMPK [38]. without significant changes in total AMPK $(p<0.001$ for $\mathrm{pAMPK} \alpha$ and $\mathrm{p}=0.001$ for $\mathrm{pACC}$ ) (Figure 6A). Phosphorylated AMPK $\alpha$ by CA was successfully blocked after an AMPK inhibitor CC treatment in the both cells (Figure 6B,C). In addition, perturbed induction of PPAR $\gamma$ and $\mathrm{C} / \mathrm{EBP} \alpha$ by CA during the differentiation was reversed by CC treatment in 3T3-L1 cells. Concurrently, the CA-induced PGC1 $\alpha$ and UCP1 expression were attenuated by CC treatment in primary brown adipocytes (Figure 6D,E). These results denote that adipocytes with AMPK deficiency is specifically affected in the expression of 
adipogenesis- and thermogenesis-related genes and proteins in both 3T3-L1 adipocytes and primary cultured brown adipocytes.

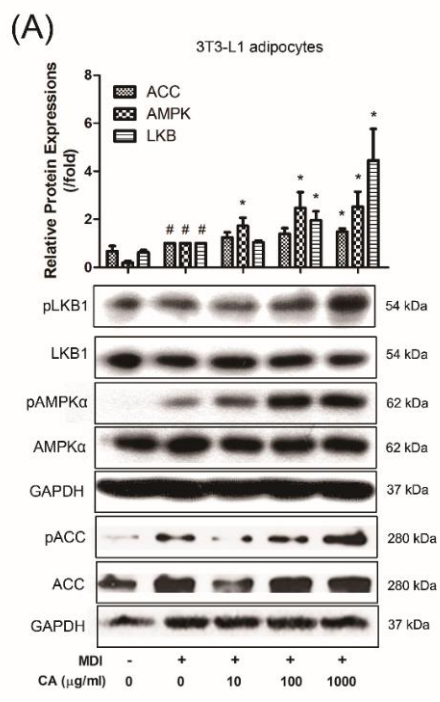

(B)

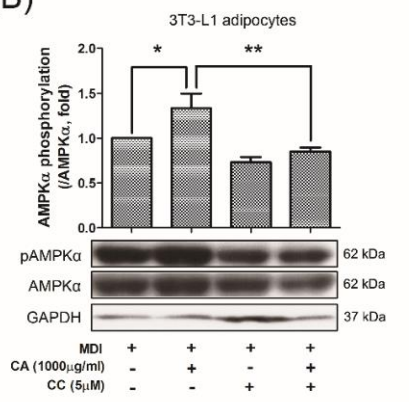

(D)

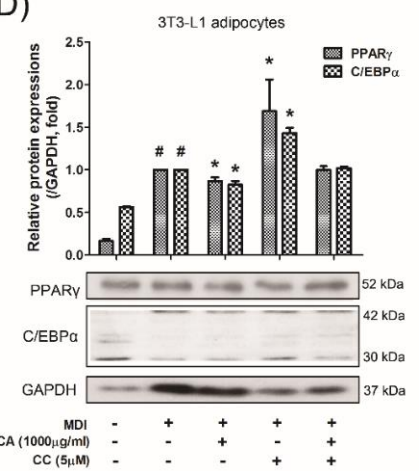

primary cultured brown adipocytes

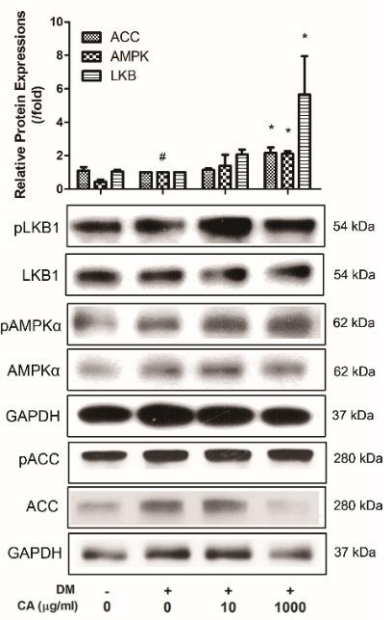

(C)

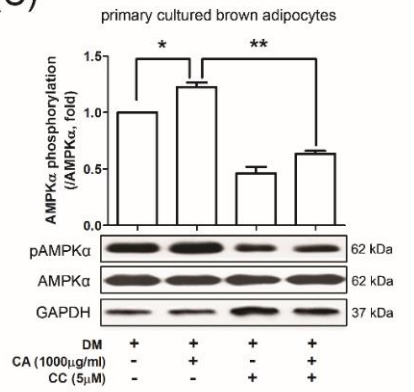

(E)

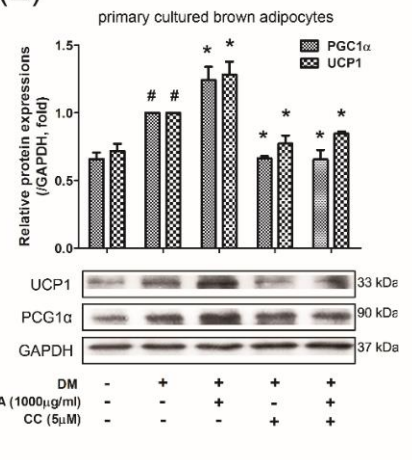

Figure 6. Effects of CA on activation of AMPK $\alpha$ pathway and in AMPK $\alpha$-inhibited conditions of 3T3-L1 cells and primary cultured brown adipocytes. (A) Phosphorylation levels of AMPK $\alpha$, LKB1 and ACC were determined in 3T3-L1 adipocytes and primary cultured brown adipocytes. pAMPK $\alpha$, LKB1 and pACC protein expressions were normalized to total AMPK $\alpha$, LKB1 and ACC, respectively. $(B, C)$ Inhibition of phosphorylation of AMPK $\alpha$ by CC co-treatment was determined by Western blot analysis. (D, E) PPAR $\gamma, \mathrm{C} / \mathrm{EBP} \alpha, \mathrm{PGC} 1 \alpha$, and UCP1 expressions under co-treatment of CA and CC were analyzed by western blot analysis. Quantification of the protein bands was measured using Image J. Results were expressed relative to GAPDH. All values are means \pm SEM of data from three separate experiments. ${ }^{\#} p<0.05$ versus MDI- or DM-uninduced preadipocytes; and ${ }^{*} p<0.05$ and ${ }^{* *} p<0.01$ versus the MDI- or DM-induced adipocytes. MDI and DM, differentiation medium; CA, bitter orange (Citrus aurantium Linné); CC, compound C. 


\section{Discussion}

Since obesity is a common chronic disease that results from dysregulated adipogenesis caused by imbalance of food intake and EE, therapeutic strategies targeting regulation of adipogenic differentiation or increase EE are both attractive approaches for combating obesity [39,40]. Generally, classic brown adipocytes increase EE by producing heat, which protects against the development of excess lipid accumulation, and eventually prevents overweight and obesity. Approaches to elevate the thermogenic activity of brown and beige adipocytes are potentially promising new strategies for preventing and treating obesity because the activity of these thermogenic adipocytes is inversely correlated with fat mass and positively related to EE [41].

Medications for obesity treatment vary, but only five are currently approved by the Food and Drug Administration (FDA) of USA [42]. However, the search for alternative treatments is still an ongoing challenge due to the various side effects of current medications. In context, some natural compounds such as polyphenol and flavonoids offer an alternative therapeutic strategy, as they can reduce the accumulation of lipid by inhibiting lipogenesis or inducing lipolysis, and subsequently decrease adiposity [43], or induce EE by increasing UCP1 in BAT [30,33]. However, there has been little evidence that CA can directly affect adipogenesis of white adipocytes and thermogenesis of brown adipocytes which are both attractive targets of anti-obese strategy. The current study evaluated the effect of CA on adipocyte differentiation in WAT and thermogenic capacity of BAT in both 3T3-L1 white adipocytes and primary cultured brown adipocytes. Our findings revealed that administration of CA significantly reduced body weight in obese mice, suggesting that CA may be potential option as an intervention to fight obesity.

Adipogenesis is a complex process of which several factors involve. Among these factors, PPAR $\gamma$ and $\mathrm{C} / \mathrm{EBP} \alpha$ are considered as the most crucial regulators of adipogenesis [11]. They mutually induce expressions, cooperate as transcription factors, and eventually leads to synergistic activation of other adipocyte factors [12]. In our study, yet the effect of CA on lipid accumulation may not seemed to be impressive (17.6\% decrease at $1000 \mu \mathrm{g} / \mathrm{mL}$ concentration), but the adipogenesis regulators, PPAR $\gamma$ and $\mathrm{C} / \mathrm{EBP} \alpha$, were suppressed by $21.6 \%$ and $34.6 \%$ respectively by CA treatment $(1000 \mu \mathrm{g} / \mathrm{mL})$, indicating a potentially strong effect on the adipogenesis cascade. The results indicated that the CA-reduced lipid accumulation is attributed to a decrease in these crucial factors associated with white adipogenesis. In addition, the genes those encode adipokines such as adipocyte protein 2 (aP2), adiponectin and resistin, were significantly suppressed by CA treatment, indicating reduced adipocyte development.

Considering the benefits and safety of BAT-mediated EE, this unique tissue can be the core of next generation for anti-obesity agents. Several factors are related to the process of non-shivering thermogenesis [44]. UCP1 in the inner membrane of mitochondria is preferably abundant in brown adipocytes. By uncoupling oxidative phosphorylation from ATP production, UCP1 converts triglyceride to heat [45]. The PR-domain containing 16 (PRDM16), transcribed from the gene Prdm16, is the inducer of the thermogenic phenotype, and activates the brown fat program in adipocytes via Pgc1a, Cidea and $C y t C[45,46]$. On the other hand, sirtuin 3 is a member of the sirtuin family of protein deacetylases which preferentially localize in mitochondria $[47,48]$, and is recently recognized as an important regulator of non-shivering thermogenesis program [49]. We found that CA promotes activation of BAT function and differentiation by upregulation of genes related to BAT thermogenesis, mitochondrial biogenesis and mitochondrial activation such as Pgc1a, Ucp1, Prdm16, Sirt3, Cidea and CytC, thereby suppress obesity by promoting EE. However, in the concept of 'browning', a rising concept of approach in obesity care of which strategy is aimed to recruit functional brown adipocytes within WAT [50], CA failed to alter any thermogenic factors including UCP1 and PGC1 $\alpha$. This allowed us to conclude CA may benefit obesity by suppressing adipogenesis of white adipocytes but not inducing 'browning' of it. The thermogenic action of CA may only happen in BAT, yet it is known that UCP1 activation in BAT can systemically affect lipolysis of WAT to produce fatty acid for thermogenic fuel supply [51].

According to previous reports, CA displays potentially beneficial effects on metabolic diseases such as obesity and type 2 diabetes [25-28]. However, the underlying mechanism of the anti-obese 
effect of CA remained obscure so far. In this study, based on the crucial role of AMPK in metabolic diseases, we attempted to reveal the effect of CA on adipogenesis and thermogenesis and assess the role of AMPK in this process. AMPK is a serine/threonine kinase of a heterodimer complex comprising a catalytic $\alpha$ subunit $(\alpha 1, \alpha 2)$ and two regulatory subunits $\beta(\beta 1, \beta 2)$ and $\gamma(\gamma 1, \gamma 2, \gamma 3)$. When AMPK $\alpha$ is phosphorylated, ATP consumption (anabolism) is inhibited and ATP production (catabolism) are activated. The overall effect of AMPK $\alpha$ activation is therefore to synthetize ATP and restore AMP:ATP and ADP:ATP ratios for the maintenance of cellular energy homeostasis [52-54]. AMPK acts as a regulator of white adipogenesis, brown adipogenesis, and brown adipocyte activation. The different role of AMPK in these three processes has been established previously. In white adipocyte differentiation (or adipogenesis), AMPK negatively regulates this process. Treatment of AICAR, the AMPK activator, in 3T3-L1 or F442A preadipocytes led to inhibition of differentiation accompanied by decreased PPAR $\gamma$ and $\mathrm{C} / \mathrm{EBP} \alpha[37,55]$. On the other hand, in brown adipocytes, AMPK is essential for their development. Deletion of AMPK $\beta$ subunits or AMPK $\alpha 1$ in mice resulted in defected brown adipocyte development $[56,57]$. Moreover, AMPK plays a crucial role in the activation of non-shivering thermogenesis in brown fat as well [58,59]. Thus, we attempted to identify whether AMPK pathway is involved in the action of CA. In consistent with previous reports on AMPK, we could observe that CA elevated phosphorylation levels of AMPK $\alpha$ and ACC both in 3T3-L1 adipocytes and primary cultured brown adipocytes. Furthermore, inhibition of AMPK $\alpha$ pathway by pre-treatment of CC lead to abolishment of the anti-adipogenic and pro-thermogenic effect of CA. Thus, we could assume the anti-obese effect of CA was dependent on the activation of AMPK $\alpha$ pathway.

Hit identification is considered as the basic level of small molecule discovery. Thus, it is necessary to identify effective constituents which can represent the effects of natural products. CA contains many compounds, including p-Octopamine and synephrine alkaloids. [26] The flavonoids, also isolated from CA, of which hesperidin and naringenin are major active compounds have been used to treat cardiovascular diseases [60]. Through and HPLC analysis, we identified two constituents which may possibly be responsible for the effect of CA. Naringin is a component derived from most citrus fruits including grapefruit and CA. Recent studies by Pu et al. [61] and Sui et al. [62] has shown that naringin can activate AMPK and thereby reduced body weight in HFD-fed obese C57BL/6J mice. Neohesperidin, another well-known compound of the Citrus genus, also has an AMPK-dependent lipid-regulating effect in vivo and vitro [63]. Further studies reported the anti-adipogenic or anti-obese effect of naringin [64-67] and neohesperidin [68,69], nevertheless, none of these have established the effect of either compound on UCP1-mediated thermogenesis. Our LC-MS data suggests that these two constituents may be responsible for the AMPK $\alpha$-dependent anti-adipogenic and thermogenic effect of CA, however, to clarify, further investigation should be carried out with different fractions and/or identified constituents.

\section{Conclusions}

In conclusion, our study revealed the underlying mechanism of the anti-adipogenic effect of $C A$, of which AMPK $\alpha$ acts as a crucial factor. Moreover, a new therapeutic possibility of CA; induction of non-shivering thermogenesis, was suggested by our study regarding primary cultured brown adipocytes. The activation of brown adipocytes was also dependent on AMPK $\alpha$ as well. Overall, we suggest $C A$ as a new potential anti-obese agent which can inhibit white adipogenesis and induce brown adipocyte thermogenesis via activation of AMPK $\alpha$.

Supplementary Materials: The following are available online at http://www.mdpi.com/2072-6643/11/9/1988/s1, Figure S1: Effect of CA on browning of 3T3-L1 adipocytes. Supplementary Table S1. Composition of experimental diets $(\mathrm{g} / \mathrm{kg})$. Supplementary Table S2. The primer sequences used for Real-Time RT-PCR.

Author Contributions: Conceptualization, J.-Y.U.; Funding Acquisition, J.P., H.J.K. and J.-Y.U.; Investigation, J.P., H.-L.K. and Y.J.; Methodology, H.J.K., K.S.A. and J.-Y.U.; Resources, H.J.K. and J.-Y.U.; Supervision, H.J.K. and J.-Y.U.; Writing-Original Draft Preparation, J.P. and H.-L.K.; Writing-Review \& Editing, J.P., H.J.K. and J.-Y.U. 
Funding: This work was supported by the National Research Foundation of Korea (NRF) grant funded by the Korea government (MSIP) (NRF-2015R1A4A1042399, 2017M3A9E4065333 and 2018R1D1A1B07049882).

Conflicts of Interest: The authors declare no conflict of interest.

\section{References}

1. WHO. Fact sheets - Obesity and overweight. Available online: https://www.who.int/en/news-room/factsheets/detail/obesity-and-overweight (accessed on 16 July 2019).

2. NCD Risk Factor Collaboration (NCD-RisC). Trends in adult body-mass index in 200 countries from 1975 to 2014: a pooled analysis of 1698 population-based measurement studies with 19.2 million participants. Lancet 2016, 387, 1377-1396. [CrossRef]

3. Bell, J.A.; Kivimaki, M.; Hamer, M. Metabolically healthy obesity and risk of incident type 2 diabetes: A meta-analysis of prospective cohort studies. Obes. Rev. 2014, 15, 504-515. [CrossRef] [PubMed]

4. Mongraw-Chaffin, M.L.; Peters, S.A.E.; Huxley, R.R.; Woodward, M. The sex-specific association between BMI and coronary heart disease: A systematic review and meta-analysis of 95 cohorts with 1.2 million participants. Lancet Diabetes Endocrinol. 2015, 3, 437-449. [CrossRef]

5. Trestini, I.; Carbognin, L.; Bonaiuto, C.; Tortora, G.; Bria, E. The obesity paradox in cancer: clinical insights and perspectives. Eat. Weight Disord. 2018, 23, 185-193. [CrossRef] [PubMed]

6. Cinti, S. Adipose Organ Development and Remodeling. Compr. Physiol. 2018, 8, 1357-1431. [CrossRef] [PubMed]

7. Morrison, S.F.; Madden, C.J.; Tupone, D. Central neural regulation of brown adipose tissue thermogenesis and energy expenditure. Cell Metab. 2014, 19, 741-756. [CrossRef]

8. Betz, M.J.; Enerback, S. Targeting thermogenesis in brown fat and muscle to treat obesity and metabolic disease. Nat. Rev. Endocrinol. 2018, 14,77-87. [CrossRef]

9. Lowe, C.E.; O’Rahilly, S.; Rochford, J.J. Adipogenesis at a glance. J. Cell Sci. 2011, 124, 2681-2686. [CrossRef]

10. Lee, J.E.; Schmidt, H.; Lai, B.; Ge, K. Transcriptional and Epigenomic Regulation of Adipogenesis. Mol. Cell Biol. 2019, 39. [CrossRef]

11. Lefterova, M.I.; Zhang, Y.; Steger, D.J.; Schupp, M.; Schug, J.; Cristancho, A.; Feng, D.; Zhuo, D.; Stoeckert, C.J., Jr.; Liu, X.S.; et al. PPARgamma and C/EBP factors orchestrate adipocyte biology via adjacent binding on a genome-wide scale. Genes Dev. 2008, 22, 2941-2952. [CrossRef]

12. Madsen, M.S.; Siersbaek, R.; Boergesen, M.; Nielsen, R.; Mandrup, S. Peroxisome proliferator-activated receptor gamma and C/EBPalpha synergistically activate key metabolic adipocyte genes by assisted loading. Mol. Cell Biol. 2014, 34, 939-954. [CrossRef] [PubMed]

13. Crowley, V.E.; Yeo, G.S.; O'Rahilly, S. Obesity therapy: Altering the energy intake-and-expenditure balance sheet. Nat. Rev. Drug Discov. 2002, 1, 276-286. [CrossRef] [PubMed]

14. Kolonin, M.G.; Saha, P.K.; Chan, L.; Pasqualini, R.; Arap, W. Reversal of obesity by targeted ablation of adipose tissue. Nat. Med. 2004, 10, 625-632. [CrossRef] [PubMed]

15. Cannon, B.; Nedergaard, J. Brown adipose tissue: Function and physiological significance. Physiol. Rev. 2004, 84, 277-359. [CrossRef] [PubMed]

16. Nedergaard, J.; Bengtsson, T.; Cannon, B. Three years with adult human brown adipose tissue. Ann. N. Y. Acad. Sci. 2010, 1212, E20-E36. [CrossRef] [PubMed]

17. Villarroya, F.; Vidal-Puig, A. Beyond the sympathetic tone: the new brown fat activators. Cell Metab. 2013, 17, 638-643. [CrossRef] [PubMed]

18. Lim, S.W.; Lee, D.R.; Choi, B.K.; Kim, H.S.; Yang, S.H.; Suh, J.W.; Kim, K.S. Protective effects of a polymethoxy flavonoids-rich Citrus aurantium peel extract on liver fibrosis induced by bile duct ligation in mice. Asian Pac. J. Trop. Med. 2016, 9, 1158-1164. [CrossRef]

19. Nair, S.A.; Sr, R.K.; Nair, A.S.; Baby, S. Citrus peels prevent cancer. Phytomedicine 2018, 50, 231-237. [CrossRef]

20. Shammugasamy, B.; Valtchev, P.; Dong, Q.; Dehghani, F. Effect of citrus peel extracts on the cellular quiescence of prostate cancer cells. Food Funct. 2019, 10, 3727-3737. [CrossRef]

21. Akhlaghi, M.; Shabanian, G.; Rafieian-Kopaei, M.; Parvin, N.; Saadat, M.; Akhlaghi, M. Citrus aurantium blossom and preoperative anxiety. Rev. Bras. Anestesiol. 2011, 61, 702-712. [CrossRef] 
22. Costa, C.A.; Cury, T.C.; Cassettari, B.O.; Takahira, R.K.; Florio, J.C.; Costa, M. Citrus aurantium L. essential oil exhibits anxiolytic-like activity mediated by 5-HT(1A)-receptors and reduces cholesterol after repeated oral treatment. BMC Complement. Altern. Med. 2013, 13, 42. [CrossRef] [PubMed]

23. Ghasemi, K.; Ghasemi, Y.; Ebrahimzadeh, M.A. Antioxidant activity, phenol and flavonoid contents of 13 citrus species peels and tissues. Pak. J. Pharm. Sci. 2009, 22, 277-281. [PubMed]

24. Wang, Q.H.; Shu, Z.P.; Xu, B.Q.; Xing, N.; Jiao, W.J.; Yang, B.Y.; Kuang, H.X. Structural characterization and antioxidant activities of polysaccharides from Citrus aurantium L. Int. J. Biol. Macromol. 2014, 67, 112-123. [CrossRef] [PubMed]

25. Alarcon-Aguilara, F.J.; Roman-Ramos, R.; Perez-Gutierrez, S.; Aguilar-Contreras, A.; Contreras-Weber, C.C.; Flores-Saenz, J.L. Study of the anti-hyperglycemic effect of plants used as antidiabetics. J. Ethnopharmacol. 1998, 61, 101-110. [CrossRef]

26. Haaz, S.; Fontaine, K.R.; Cutter, G.; Limdi, N.; Perumean-Chaney, S.; Allison, D.B. Citrus aurantium and synephrine alkaloids in the treatment of overweight and obesity: An update. Obes. Rev. 2006, 7, 79-88. [CrossRef] [PubMed]

27. Campbell, J.I.; Mortensen, A.; Molgaard, P. Tissue lipid lowering-effect of a traditional Nigerian anti-diabetic infusion of Rauwolfia vomitoria foilage and Citrus aurantium fruit. J. Ethnopharmacol. 2006, 104, 379-386. [CrossRef] [PubMed]

28. Raciti, G.A.; Fiory, F.; Campitelli, M.; Desiderio, A.; Spinelli, R.; Longo, M.; Nigro, C.; Pepe, G.; Sommella, E.; Campiglia, P.; et al. Citrus aurantium L. dry extracts promote C/ebpbeta expression and improve adipocyte differentiation in 3T3-L1 cells. PLoS ONE 2018, 13, e0193704. [CrossRef]

29. Kim, H.L.; Park, J.; Park, H.; Jung, Y.; Youn, D.H.; Kang, J.; Jeong, M.Y.; Um, J.Y. Platycodon grandiflorum A. De Candolle Ethanolic Extract Inhibits Adipogenic Regulators in 3T3-L1 Cells and Induces Mitochondrial Biogenesis in Primary Brown Preadipocytes. J. Agric. Food Chem. 2015, 63, 7721-7730. [CrossRef] [PubMed]

30. Kim, H.L.; Park, J.; Jung, Y.; Ahn, K.S.; Um, J.Y. Platycodin D, a novel activator of AMP-activated protein kinase, attenuates obesity in $\mathrm{db} / \mathrm{db}$ mice via regulation of adipogenesis and thermogenesis. Phytomedicine 2019, 52, 254-263. [CrossRef]

31. Kwak, H.J.; Jeong, M.Y.; Um, J.Y.; Park, J. beta -Lapachone Regulates Obesity through Modulating Thermogenesis in Brown Adipose Tissue and Adipocytes: Role of AMPK Signaling Pathway. Am. J. Chin. Med. 2019, 47, 803-822. [CrossRef]

32. Han, H.Y.; Lee, S.K.; Choi, B.K.; Lee, D.R.; Lee, H.J.; Kim, T.W. Preventive Effect of Citrus aurantium Peel Extract on High-Fat Diet-Induced Non-alcoholic Fatty Liver in Mice. Biol. Pharm. Bull. 2019, 42, 255-260. [CrossRef] [PubMed]

33. Jung, Y.; Park, J.; Kim, H.L.; Sim, J.E.; Youn, D.H.; Kang, J.; Lim, S.; Jeong, M.Y.; Yang, W.M.; Lee, S.G.; et al. Vanillic acid attenuates obesity via activation of the AMPK pathway and thermogenic factors in vivo and in vitro. Faseb. J. 2018, 32, 1388-1402. [CrossRef] [PubMed]

34. Adams, A.E.; Hanrahan, O.; Nolan, D.N.; Voorheis, H.P.; Fallon, P.; Porter, R.K. Images of mitochondrial UCP 1 in mouse thymocytes using confocal microscopy. Biochim. Biophys. Acta 2008, 1777, 115-117. [CrossRef] [PubMed]

35. Chouchani, E.T.; Kazak, L.; Spiegelman, B.M. New Advances in Adaptive Thermogenesis: UCP1 and Beyond. Cell Metab. 2019, 29, 27-37. [CrossRef] [PubMed]

36. Pirkmajer, S.; Kulkarni, S.S.; Tom, R.Z.; Ross, F.A.; Hawley, S.A.; Hardie, D.G.; Zierath, J.R.; Chibalin, A.V. Methotrexate promotes glucose uptake and lipid oxidation in skeletal muscle via AMPK activation. Diabetes 2015, 64, 360-369. [CrossRef] [PubMed]

37. Habinowski, S.A.; Witters, L.A. The effects of AICAR on adipocyte differentiation of 3T3-L1 cells. Biochem. Biophys. Res. Commun. 2001, 286, 852-856. [CrossRef]

38. Jeon, S.M. Regulation and function of AMPK in physiology and diseases. Exp. Mol. Med. 2016, 48 , e245. [CrossRef] [PubMed]

39. Tam, C.S.; Lecoultre, V.; Ravussin, E. Brown adipose tissue: mechanisms and potential therapeutic targets. Circulation 2012, 125, 2782-2791. [CrossRef] [PubMed]

40. Zhang, Y.; Liu, J.; Yao, J.; Ji, G.; Qian, L.; Wang, J.; Zhang, G.; Tian, J.; Nie, Y.; Zhang, Y.E.; et al. Obesity: Pathophysiology and intervention. Nutrients 2014, 6, 5153-5183. [CrossRef] 
41. Saito, M.; Okamatsu-Ogura, Y.; Matsushita, M.; Watanabe, K.; Yoneshiro, T.; Nio-Kobayashi, J.; Iwanaga, T.; Miyagawa, M.; Kameya, T.; Nakada, K.; et al. High incidence of metabolically active brown adipose tissue in healthy adult humans: Effects of cold exposure and adiposity. Diabetes 2009, 58, 1526-1531. [CrossRef]

42. Pilitsi, E.; Farr, O.M.; Polyzos, S.A.; Perakakis, N.; Nolen-Doerr, E.; Papathanasiou, A.E.; Mantzoros, C.S. Pharmacotherapy of obesity: Available medications and drugs under investigation. Metabolism 2019, 92, 170-192. [CrossRef] [PubMed]

43. Velusami, C.C.; Agarwal, A.; Mookambeswaran, V. Effect of Nelumbo nucifera Petal Extracts on Lipase, Adipogenesis, Adipolysis, and Central Receptors of Obesity. Evid. Based Complement. Alternat. Med. 2013, 2013, 145925. [CrossRef] [PubMed]

44. Frontini, A.; Cinti, S. Distribution and development of brown adipocytes in the murine and human adipose organ. Cell Metab. 2010, 11, 253-256. [CrossRef] [PubMed]

45. Seale, P.; Kajimura, S.; Yang, W.; Chin, S.; Rohas, L.M.; Uldry, M.; Tavernier, G.; Langin, D.; Spiegelman, B.M. Transcriptional control of brown fat determination by PRDM16. Cell Metab. 2007, 6, 38-54. [CrossRef] [PubMed]

46. Seale, P.; Conroe, H.M.; Estall, J.; Kajimura, S.; Frontini, A.; Ishibashi, J.; Cohen, P.; Cinti, S.; Spiegelman, B.M. Prdm16 determines the thermogenic program of subcutaneous white adipose tissue in mice. J. Clin. Investig. 2011, 121, 96-105. [CrossRef] [PubMed]

47. Lombard, D.B.; Alt, F.W.; Cheng, H.L.; Bunkenborg, J.; Streeper, R.S.; Mostoslavsky, R.; Kim, J.; Yancopoulos, G.; Valenzuela, D.; Murphy, A.; et al. Mammalian Sir2 homolog SIRT3 regulates global mitochondrial lysine acetylation. Mol. Cell Biol. 2007, 27, 8807-8814. [CrossRef] [PubMed]

48. Kong, X.; Wang, R.; Xue, Y.; Liu, X.; Zhang, H.; Chen, Y.; Fang, F.; Chang, Y. Sirtuin 3, a new target of PGC-1alpha, plays an important role in the suppression of ROS and mitochondrial biogenesis. PLoS ONE 2010, 5, e11707. [CrossRef] [PubMed]

49. Sebaa, R.; Johnson, J.; Pileggi, C.; Norgren, M.; Xuan, J.; Sai, Y.; Tong, Q.; Krystkowiak, I.; Bondy-Chorney, E.; Davey, N.E.; et al. SIRT3 controls brown fat thermogenesis by deacetylation regulation of pathways upstream of UCP1. Mol. Metab. 2019, 25, 35-49. [CrossRef] [PubMed]

50. Wang, S.; Pan, M.H.; Hung, W.L.; Tung, Y.C.; Ho, C.T. From white to beige adipocytes: therapeutic potential of dietary molecules against obesity and their molecular mechanisms. Food Funct. 2019, 10, 1263-1279. [CrossRef] [PubMed]

51. Shin, H.; Ma, Y.; Chanturiya, T.; Cao, Q.; Wang, Y.; Kadegowda, A.K.G.; Jackson, R.; Rumore, D.; Xue, B.; Shi, H.; et al. Lipolysis in Brown Adipocytes Is Not Essential for Cold-Induced Thermogenesis in Mice. Cell Metab. 2017, 26, 764-777. [CrossRef] [PubMed]

52. Hardie, D.G. AMPK-sensing energy while talking to other signaling pathways. Cell Metab. 2014, 20,939-952. [CrossRef] [PubMed]

53. Hardie, D.G.; Lin, S.C. AMP-activated protein kinase - not just an energy sensor. F1000Res 2017, 6, 1724. [CrossRef] [PubMed]

54. Hardie, D.G. Keeping the home fires burning: AMP-activated protein kinase. J. R. Soc. Interface $2018,15$. [CrossRef] [PubMed]

55. Dagon, Y.; Avraham, Y.; Berry, E.M. AMPK activation regulates apoptosis, adipogenesis, and lipolysis by eIF2alpha in adipocytes. Biochem. Biophys. Res. Commun. 2006, 340, 43-47. [CrossRef] [PubMed]

56. Mottillo, E.P.; Desjardins, E.M.; Crane, J.D.; Smith, B.K.; Green, A.E.; Ducommun, S.; Henriksen, T.I.; Rebalka, I.A.; Razi, A.; Sakamoto, K.; et al. Lack of Adipocyte AMPK Exacerbates Insulin Resistance and Hepatic Steatosis through Brown and Beige Adipose Tissue Function. Cell Metab. 2016, 24, 118-129. [CrossRef] [PubMed]

57. Zhao, J.; Yang, Q.; Zhang, L.; Liang, X.; Sun, X.; Wang, B.; Chen, Y.; Zhu, M.; Du, M. AMPK $\alpha 1$ deficiency suppresses brown adipogenesis in favor of fibrogenesis during brown adipose tissue development. Biochem. Biophys. Res. Commun. 2017, 491, 508-514. [CrossRef] [PubMed]

58. Hutchinson, D.S.; Chernogubova, E.; Dallner, O.S.; Cannon, B.; Bengtsson, T. Beta-adrenoceptors, but not alpha-adrenoceptors, stimulate AMP-activated protein kinase in brown adipocytes independently of uncoupling protein-1. Diabetologia 2005, 48, 2386-2395. [CrossRef] [PubMed]

59. Beiroa, D.; Imbernon, M.; Gallego, R.; Senra, A.; Herranz, D.; Villarroya, F.; Serrano, M.; Fernø, J.; Salvador, J.; Escalada, J.; et al. GLP-1 agonism stimulates brown adipose tissue thermogenesis and browning through hypothalamic AMPK. Diabetes 2014, 63, 3346-3358. [CrossRef] 
60. Kim, G.S.; Park, H.J.; Woo, J.H.; Kim, M.K.; Koh, P.O.; Min, W.; Ko, Y.G.; Kim, C.H.; Won, C.K.; Cho, J.H. Citrus aurantium flavonoids inhibit adipogenesis through the Akt signaling pathway in 3T3-L1 cells. BMC Complement. Altern. Med. 2012, 12, 31. [CrossRef]

61. Pu, P.; Gao, D.M.; Mohamed, S.; Chen, J.; Zhang, J.; Zhou, X.Y.; Zhou, N.J.; Xie, J.; Jiang, H. Naringin ameliorates metabolic syndrome by activating AMP-activated protein kinase in mice fed a high-fat diet. Arch. Biochem. Biophys. 2012, 518, 61-70. [CrossRef]

62. Sui, G.G.; Xiao, H.B.; Lu, X.Y.; Sun, Z.L. Naringin Activates AMPK Resulting in Altered Expression of SREBPs, PCSK9, and LDLR To Reduce Body Weight in Obese C57BL/6J Mice. J. Agric. Food Chem. 2018, 66, 8983-8990. [CrossRef] [PubMed]

63. Wu, H.; Liu, Y.; Chen, X.; Zhu, D.; Ma, J.; Yan, Y.; Si, M.; Li, X.; Sun, C.; Yang, B.; et al. Neohesperidin Exerts Lipid-Regulating Effects in vitro and in vivo via Fibroblast Growth Factor 21 and AMP-Activated Protein Kinase/Sirtuin Type 1/Peroxisome Proliferator-Activated Receptor Gamma Coactivator 1alpha Signaling Axis. Pharmacology 2017, 100, 115-126. [CrossRef] [PubMed]

64. Jung, U.J.; Lee, M.K.; Park, Y.B.; Kang, M.A.; Choi, M.S. Effect of citrus flavonoids on lipid metabolism and glucose-regulating enzyme mRNA levels in type-2 diabetic mice. Int. J. Biochem. Cell Biol. 2006, 38, 1134-1145. [CrossRef] [PubMed]

65. Morikawa, K.; Nonaka, M.; Mochizuki, H.; Handa, K.; Hanada, H.; Hirota, K. Naringenin and hesperetin induce growth arrest, apoptosis, and cytoplasmic fat deposit in human preadipocytes. J. Agric. Food Chem. 2008, 56, 11030-11037. [CrossRef] [PubMed]

66. Alam, M.A.; Kauter, K.; Brown, L. Naringin improves diet-induced cardiovascular dysfunction and obesity in high carbohydrate, high fat diet-fed rats. Nutrients 2013, 5, 637-650. [CrossRef] [PubMed]

67. Wang, D.; Yan, J.; Chen, J.; Wu, W.; Zhu, X.; Wang, Y. Naringin Improves Neuronal Insulin Signaling, Brain Mitochondrial Function, and Cognitive Function in High-Fat Diet-Induced Obese Mice. Cell Mol. Neurobiol. 2015, 35, 1061-1071. [CrossRef] [PubMed]

68. Jia, S.; Hu, Y.; Zhang, W.; Zhao, X.; Chen, Y.; Sun, C.; Li, X.; Chen, K. Hypoglycemic and hypolipidemic effects of neohesperidin derived from Citrus aurantium L. in diabetic KK-A(y) mice. Food Funct. 2015, 6, 878-886. [CrossRef] [PubMed]

69. Han, G.E.; Kang, H.T.; Chung, S.; Lim, C.; Linton, J.A.; Lee, J.H.; Kim, W.; Kim, S.H.; Lee, J.H. Novel Neohesperidin Dihydrochalcone Analogue Inhibits Adipogenic Differentiation of Human Adipose-Derived Stem Cells through the Nrf2 Pathway. Int. J. Mol. Sci. 2018, 19. [CrossRef] [PubMed] 